\title{
PROPOSED DETERMINATION OF THE NOMINAL SPECIES TO BE ACCEPTED AS THE TYPE SPECIES OF THE GENUS “INOCERA- MUS " SOWERBY (J.), 1814 (CLASS PELECYPODA) AND PROPOSED ADDITION OF THAT NAME TO THE “ OFFICIAL LIST OF GENERIC NAMES IN ZOOLOGY"
}

\author{
By L. R. Cox, Sc.D., F.R.S. \\ (British Museum (Natural History), London)
}

(Commission's reference : Z.N.(S.) 629)

The object of the present application is to seek from the International Commission a Ruling as to the nominal species to be adopted as the type species of the genus Inoceramus Sowerby (J.), 1814 (Class Pelecypoda) and to request that the name of this nominal genus, with its type species so defined, be placed on the Official List of Generic Names in Zoology.

2. The generic name Inoceramus was first proposed by Sowerby (J.) in a paper entitled : "On a fossil shell of a fibrous structure, the fragments of which occur abundantly in the Chalk Strata and in the flints accompanying it". This paper was presented to the Linnean Society of London on lst November 1814, but was not actually published until some date late in 1822 and possibly later* (Trans. linn. Soc. Lond. $13: 453-458$, pl. 25). Some particulars of the contents of this paper must have been made public at the meeting of the Linnean Society at which it was presented, for the following notice regarding it was published in 1814 ([Anon.], Ann. Phil. 4:448) :-

\section{Proceedings of Philosophical Societies}

\section{LINNEAN SOCIETY}

The Society resumed its meetings on Tuesday, the lst of November.

A paper by Mr. Sowerby was read on a fossil shell which occurs in chalk, very frequently in the flint nodules. Fragments of it had been observed by Cuvier and Brongniart in the chalk near Paris, and from their fibrous texture they were led to consider them as fragments of pinnae; but from their thickness (near half an inch) they concluded that the shell must have been of enormous size. Mr. Sowerby got specimens of the fossil from various quarters of the chalk country in the south of England. He ascertained, by comparing these specimens with each other, that it was a bivalve shell, having a hinge of a peculiar structure, and constituting a genus apart. To this genus he had given the name of inoceramus; and the most common species he calls Inoceramus Cuvierii.

* This paper was certainly published after October 1822, since on page 692 there appears a notice of the receipt by the Linnean Society's Library of No. 294 of Tulloch's Philosophical Magazine, which is dated 31st October 1822. It is possible that this paper was not published until 1823, since the Geological Society's Library did not receive its copy until 19th April 1823.

Bull. zool. Nomencl. Vol. 11, Part 8. July 1955. 
3. The first point which calls for consideration is the authorship to be attributed to the generic name Inoceramus and the binomen Inoceramus cuvierii as published in the foregoing notice. As already noted, the passage quoted above, though probably written by $\mathrm{T}$. Thomson, who was at that time the editor of the Annals of Philosophy, was published anonymously. The passage itself makes it absolutely clear however that both the new names introduced in it were destined later to appear in Sowerby's paper and also that the "indications" given in that passage for the new taxa so named were drawn from Sowerby's paper. The question therefore arises as to the attribution to be given to these names. In my view the proper course in such a case would be to attribute the names in question to the author (Sowerby) by whom they were proposed and by whom the "indications " (for the purposes of Article 25 of the Règles) were provided rather than to treat these names as having been published anonymously, with, or without, a doubtful attribution to Thomson, the editor of the serial publication in which they were published. This question however raises an issue of principle on which no Ruling has ever been given either by the International Congress of Zoology or by the International Commission acting on its behalf. I have discussed this matter with the Secretary to the Commission who has informed me that a number of other cases of this kind has arisen, including at least one which affects the authorship to be attributed to names already placed on one or other of the Official Lists. Mr. Hemming has accordingly decided himself to present to the Commission a request for a Declaration that in cases of the foregoing kind the names in question are to be attributed to the authors by whom they were proposed and by whom either the "indication" or the material for that "indication" were provided. Arrangements have been made for Mr. Hemming's application (Z.N.(S.)891) to be published immediately before the present application, so that the two associated problems may be considered by the Commission at the same time. Beyond expressing my full support for Mr. Hemming's application, I need add only that in the present application I have assumedas some working hypothesis is necessary - that the proposals submitted in that application will meet with the approval of the Commission. Accordingly, in the remainder of the present application I have treated the two names with which we are here concerned as being attributable to Sowerby.

4. The next point which requires to be considered is whether the particulars given in the passage published by Thomson contain sufficient information (1) to qualify as " indications" for the purposes of Proviso (a) to Article 25 of the Règles and (2) to permit of the identification of the taxa so named.

5. On the first of these questions there can, I think, be no doubt that the particulars given in the passage quoted in paragraph 2 above must be regarded as constituting an "indication " for the purposes of Article 25 for the nominal genus Inoceramus, for the author of the passage gave a number of separate items of information regarding the nominal genus to which this name was 
applied (e.g. that the species included in it was a fossil shell of fibrous texture ; that it was a shell of very large size ; that it was a bivalve with a hinge of a peculiar type ; that it had been obtained from the Chalk). No separate particulars were given for the nominal species Inoceramus cuvierii, but the particulars then given for the genus Inoceramus apply also to this species, which must therefore be regarded also as having been published with an indication. The particulars given are fully sufficient to enable anyone with a knowledge of Chalk fossils to identify the group to which the fossil here in question belongs. I accordingly conclude (a) that the nominal genus Inoceramus was duly provided with an "indication" at the time when the foregoing generic name was published in 1814 and (b) that the "indication " so given is sufficient to permit of a definite identification of the genus so named.

6. The position is more complicated when we turn to consider whether the specific name cuvierii Sowerby (J.), 1814, as published in the combination Inoceramus cuvierii, can be regarded as having been published with an "indication " for the purposes of Article 25. There is no doubt that the answer to this question would be in the affirmative if Sowerby had stated that he was erecting the new genus Inoceramus solely for the purpose of providing a generic name for the new species Inoceramus cuvierii, for in that event the description given would clearly have provided an "indication" both for the generic name Inoceramus and for the name Inoceramus cuvierii (1950, Bull. zool. Nomencl. $4: 149$, codifying Opinion 43). But this is not what he did, for as the passage quoted in paragraph 2 of the present application shows, he clearly considered that this genus contained several species, of which, however, he regarded the foregoing as "the most common species". At this point therefore we have to consider whether from the nomenclatorial standpoint the genus Inoceramus, when first established, contained (a) only the nominal species Inoceramus cuvierii, the sole such species cited, or (b) whether, in addition, it contained also certain other species not cited by name by Sowerby. On this question a clear answer is provided by the decision by the Thirteenth International Congress of Zoology, Paris, 1948, to insert in the Règles a provision that, "where a genus is established without a designated or indicated type species and only one nominal species is cited as being referable to that genus, the nominal species so cited is the type species of the genus by monotypy, irrespective of whether or not the author concerned regarded the genus as monotypical " $(1950$, Bull. zool. Nomencl. $4: 153$ ). Under this provision the genus Inoceramus Sowerby, 1814, is therefore to be regarded as being, for nomenclatorial purposes, monotypical. Accordingly the Ruling given in Opinion 43 referred to above applies in this case, and the description given by Sowerby provides the name Inoceramus cuvierii Sowerby, 1814, as well as the generic name Inoceramus Sowerby, with an "indication". The name Inoceramus cuvierii Sowerby is thus an available name for the purpose of nomenclature.

7. The next point to be considered is whether the "indication" given by Sowerby for his Inoceramus cuvierii is sufficient to permit of the identification 
of the species so named or whether from the taxonomic point of view the above name must be put on one side as a nomen dubium. If we were required for this purpose to rely solely upon the published words, it would not be possible to establish a definite identification from these words, for there several species which are quite common at particular horizons. But here it is necessary to take into account another decision by the Paris (1948) Congress, namely that in which it clarified the status of a holotype or lectotype in relation to an inadequate original description. On this subject the Congress decided that the provisions of Article 31 relating to holotypes and lectotypes were applicable in this type of case in the same way as in any other case (1950, Bull. zool. Nomencl. $4: 292-293$ ). An example of a case where this principle has already been applied by the Commission is provided by the case of the name Pholidocidaris Meek \& Worthen, 1869 (Class Echinoidea). The facts of this case, which was first submitted to the Commission by the late Dr. Mortensen and others in 1932 (Ann. Mag. nat. Hist. (10) $10: 345-368$ ), were summarised by Mr. Hemming, as Secretary to the Commission, in a note published in 1952 (Bull. zool. Nomencl. $7: 219-220$ ). In this case there were two nominal genera, of which the later, Pholidocidaris Meek \& Worthen, 1869, was in general use, while the older name Protoechinus Austin, 1860, had long been treated as a nomen dubium, owing to the impossibility of identifying with certainty its type species, Protoechinus anceps Austin. Bather (1918) showed however that the holotype of anceps Austin was a species belonging to the genus then known by the name Pholidocidaris and in consequence that that generic name was a junior subjective synonym of Protoechinus Austin. To prevent the confusion which this change of name would produce the Commission was asked to suppress the name Protoechinus under its Plenary Powers, thereby retaining Pholidocidaris as the oldest available name for this genus. Mr. Hemming informs me that the application submitted in this case has now been approved by the Commission and has been embodied in Opinion 373, now in the press.

8. It is necessary therefore at this point to enquire if any syntypes of Sowerby's Inoceramus cuvierii of 1822 and therefore of 1814 (the paper of the earlier year being no more than an abstract of that of 1822) are still extant. The British Museum Collection contains one specimen which is undoubtedly one of the two figured syntypes and another labelled with a query as the other, but which differs greatly from the figure. Of these specimens Woods (1912, Cret. Lamellibr. England $2: 315$, text-fig. 73) referred to the first as "the type". It could be argued that this action could be regarded as constituting the selection of that specimen to be the lectotype of Inoceramus cuvierii. In view, however, of the possibility that the opposite view might be held, and, as no later author has dealt with this subject, I take this opportunity hereby formally to select this specimen to be the lectotype of this species. It is the specimen represented in J. Sowerby's (1822) pl. 25, figs. 2 and 3, which was re-figured by J. de C. Sowerby in 1923 (Min. Conch. 5 : pl. 441, fig. 1). 
9. The labels attached to, or associated with, the lectotype now selected are the following :-

(1) Labels attached to the specimen:

(a) a yellow ticket with the Registration Number 43264 ;

(b) a small green ticket indicating " figured specimen";

(c) a label in very old handwriting, possibly that of J. de C. Sowerby, with the words " Inoceramus Linn. Soc. 1 Novr. 1814 M.C.441 ";

(d) a small label with the words " Inoceramus Cuvieri M.C.441 f.1 ";

(2) Labels associated with the specimen:

(a) a standard label of recent origin, with information regarding the provenance and history of the specimen ;

(b) a label "Lectotype, Cox, 1955 ".

10. By the lectotype selection made in this case the name Inoceramus cuvierii Sowerby (J.), 1814, is firmly linked to the species figured (pl. 25, figs. 1-3) under this name by Sowerby in 1822. Since Inoceramus cuvierii Sowerby, 1814, is the sole nominal species cited by Sowerby at the time when he published the generic name Inoceramus, this species is, as we have seen, the type species by monotypy of the genus so named. The indication of this species as the type species under Rule (c) in Article 30 replaces the selection under Rule $(\mathrm{g})$ in that Article of Inoceramus Lamarckii Parkinson, 1819 (Trans. geol. Soc. Lond. 5(1) : 55) as the type species made by myself in 1928 (Quart. J. geol. Soc. Lond. $84: 233-245$ ) long before the decisions by the Paris Congress discussed in paragraphs 6 and 7 above made it clear that Inoceramus cuvierii Sowerby, 1814, was a name duly provided with an "indication" as required by Article 25 and not a nomen nudum, as I then considered it to be. This adjustment of the species to be accepted as the type species of the genus Inoceramus will involve no change in the concept represented by this genus, for $I$. cuvierii Sowerby, 1814 (=I. cuvierii Sowerby, 1822) and I. lamarckii Parkinson, 1819, are currently treated as being congeneric with one another.

11. I recommend that the Commission, when dealing with the present case, should take the opportunity to place on the Official Index of Rejected and Invalid Specific Names in Zoology the specific names comprised in the three binomina which are junior homonyms of Inoceramus cuvierii Sowerby, 1814. These are :-(1) Inoceramus cuvierii Smith (W.), 1816 (Strata organ. Foss. : 10, "Lower Chalk" pl., fig. 1). I have shown (Cox, 1930, Ann. Mag. nat. Hist. (10) $6: 291$ ), on the basis of an examination of Smith's figured specimen, which is preserved in the British Museum, that this binomen applies to an entirely different species, now placed in a different genus. The species concerned 
is Inoceramus involutus Sowerby (J. de C.), 1828 (Min. Conch. 6 : 160), which is the type species by original designation of the genus Volviceramus Stoliczka, 1871 (Cret. Faun. S. India, Pelecypoda : 394). (2) Inoceramus cuvieri, Mantell, 1822 [May] (Foss. S. Downs : 213, pl. 27, fig. 4 ; pl. 28, figs. 1, 4), which Woods (1911, Cret. Lamellibr. England $2: 314)$ identified as the typical form of Inoceramus lamarckii Parkinson. (3) Inoceramus cuvierii Sowerby (J.), [1822, post-Oct.] (Trans. linn. Soc. Lond. $13: 457$, pl. 25, figs. 1-3), which, as already explained, is a junior objective synonym of, as well as a junior primary homonym of, Inoceramus cuvierii Sowerby (J.), 1814.

12. The nominal genus Inoceramus Sowerby was made the type genus of a subfamily inoceraminae by Zittel in 1881 (Handb. Palaeont., Pal. 2 : 36). Zittel has not been followed by later authors, with the exception of Heinz (1932, Mitt. min.-geol. Staatsint. Hamburg 13:5). By other authors the genus Inoceramus has been treated as belonging to the same family-group taxon as the genus Isognomon [Humphrey (ex Solander)], 1786 (Cat. Portland Mus. : 41). There is not agreement however as to the use of this name for this genus or as to what name should be used for the family-group so recognised. This is a matter which ought to be settled with as little further delay as possible, and it is my intention to submit an application on this subject to the International Commission. So far as the present case is concerned, I recommend that, in accordance with the procedure prescribed by the International Congress of Zoology, the Commission should place the family-group name INOCERAMINAE Zittel, 1881, on the Official List of Family-Group Names in Zoology, with a note that it has been so added for use by specialists who consider that the genus Inoceramus Sowerby, 1814, should be placed in a family-group taxon not possessing an older name.

13. In the light of the considerations advanced in the present application, the International Commission is asked :-

(1) to place the under-mentioned generic names on the Official List of Generic Names in Zoology :-

(a) Inoceramus Sowerby (J.), 1814 (gender : masculine) (type species, by monotypy: Inoceramus cuvierii Sowerby (J.), 1814, as defined by the present lectotype selection by Cox);

(b) Volviceramus Stoliczka, 1871 (gender: masculine) (type species, by original designation : Inoceramus involutus Sowerby (J. de C.), 1828);

(2) to place the under-mentioned specific names on the Official List of Specific Names in Zoology :-

(a) cuvierii Sowerby (J.), 1814, as published in the combination Inoceramus cuvierii and as defined by the lectotype selection specified in (1)(a) above (specific name of type species of Inoceramus Sowerby (J.), 1814); 
(b) involutus Sowerby (J. de C.), 1828, as published in the combination Inoceramus involutus (specific name of type species of Volviceramus Stoliczka, 1871);

(c) lamarckii Parkinson, 1819, as published in the combination Inoceramus lamarckii;

(3) to place the under-mentioned specific names on the Official Index of Rejected and Invalid Specific Names in Zoology :-

(a) the under-mentioned junior primary homonyms of cuvierii Sowerby (J.), 1814, as published in the combination Inoceramus cuvierii :-

(i) cuvieri Smith (W.), 1816, as published in the combination Inoceramus cuvieri;

(ii) cuvieri Mantell, 1822 [May], as published in the combination Inoceramus cuvieri;

(b) cuvierii Sowerby (J.), [1822 post Oct.], as published in the combination Inoceramus cuvierii (a junior primary homonym of, and a junior objective synonym of, cuvierii Sowerby (J.), 1814, as published in the combination Inoceramus cuvierii.

(4) to place the under-mentioned name on the Official List of FamilyGroup Names in Zoology: INOCERAMINAE Zittel, 1881 (type genus: Inoceramus Sowerby (J.), 1814) (with a note that this name has been so added for use by specialists who place the genus Inoceramus Sowerby in a family-group taxon not possessing an older name). 

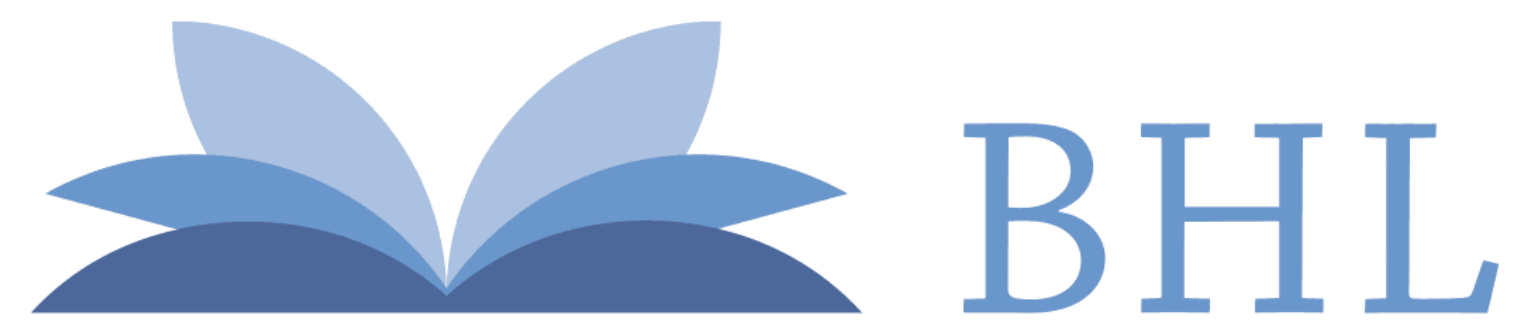

\section{Biodiversity Heritage Library}

Cox, L R. 1955. "Proposed determination of the nominal species to be accepted as the type species of the genus "Inoceramus" Sowerby (J.), 1814 (Class Pelecypoda) and proposed addition of that name to the "Official List of Generic Names in Zoology."." The Bulletin of zoological nomenclature 11, 239-245. https://doi.org/10.5962/bhl.part.2846.

View This Item Online: https://www.biodiversitylibrary.org/item/44292

DOI: https://doi.org/10.5962/bhl.part.2846

Permalink: https://www.biodiversitylibrary.org/partpdf/2846

\section{Holding Institution}

Natural History Museum Library, London

\section{Sponsored by}

Natural History Museum Library, London

\section{Copyright \& Reuse}

Copyright Status: In copyright. Digitized with the permission of the rights holder.

License: http://creativecommons.org/licenses/by-nc-sa/3.0/

Rights: https://biodiversitylibrary.org/permissions

This document was created from content at the Biodiversity Heritage Library, the world's largest open access digital library for biodiversity literature and archives. Visit BHL at https://www.biodiversitylibrary.org. 